\title{
Maximum Profit on the Electrical Appliance Store in Sidoarjo
}

\author{
Icha Almasha Vilantika Poetri, Verina Aldera Pratama, Evi Thelia Sari
}

\begin{abstract}
This research is based on Microeconomic Theory about the quantity of production that provides maximum profit. The purpose of this research is to find out and analyze how much quantity of product $(Q)$ for sale, which gives the maximum profit, in the Electrical Appliance StoreElectric Shop business in the suko market, suko village, sidoarjo-sidoarjo. Data is quantitative, sourced directly from the object of research (primary data). Data collection method using interview and documentation instruments in Oktober 2019 - March 2020 and the data presentedis sales data per month and the product we examne are Lamps. The analytical tool used is the Maximum Profit Analysis with the Total Approach which compares total revenue with total cost (TR - TC), and the Marginal Appoarch method, which is a condition where marginal revenue is equal to marginal cost (MR $=M C)$. The results of this research are seen from the data that is already available, pointed MR>MC. That means the electrical equipment store "Ayu sell" has not reached the point of maximum profit.
\end{abstract}

Keywords: maximize, profit, production quantity, total revenue, total cost.

\section{INTRODUCTION}

C ommunity needs for electrical equipment and cannot be separated from the incessant housing construction projects, shopping centres or retails, factories, and offices, which trigger high demand for products electrical products. The rapid development of technology and human knowledge, making requests or requests for power tools and the like as well experienced very significant increase. Therefore, the business of electrical appliances also experienced rapid development with a variety of sophisticated, practical and useful electrical equipment products.

These opportunities also encourage many people to then open up electricity business, be it a shop that sells retail or is a distributor of equipment electricity. Because this business opportunity is very promising and has good prospects bright for the future and does not require too much capital compared to food / culinary business that has a risk of damage or stale if the merchandise sold does not sell, sales of electrical appliances do not have expiration that can hurt the seller. So that not a few people choose the power tools business as their new venture.

Revised Manuscript Received on May 15, 2020.

* Correspondence Author

Icha Almasha Vilantika Poetri*, Student, STIE Mahardhika, Surabaya Indonesia. Indonesia.

Evi Thelia Sari, Senior Lecturer, Department of Management, STIE Mahardhika, Surabaya Indonesia.

(c) The Authors. Published by Blue Eyes Intelligence Engineering and Sciences Publication (BEIESP). This is an open access article under the CC BY-NC-ND license (http://creativecommons.org/licenses/by-nc-nd/4.0/)
Verina Aldera Pratama, Student, STIE Mahardhika, Surabaya

Therefore, the author has an interest in raising the business of electrical appliance shops given the many needs of electrical appliances today because of the many new housing developments and so on.

Obviously a positive impact on business owners of electrical appliance shops, because demand is increasing and profits are also increasing.

The author chose Electrical Appliance Storeshop as a place of research because Electrical Appliance Storeshop is one of the shops that sell electrical appliances. Located at Suko market, Suko village, Sidoarjo. the location is very strategic because it is in the middle of the city. then in one of the Shop houses that trade in the traditional market. That way the store is easy to know, easy to reach, there are many possibilities that customers will buy at the store.

Business activities will lead to efforts to obtain maximum profit or profit. Of course, taking into account all costs, which in turn the company will set a profit target for each product produced. Simply put, the profit for the company is when the production costs are less than the selling price of the product it produces. In economics known as the input is smaller than the output. In the short term efforts to maximize profits by the company, can be explained in 1 (one) way, namely: Comparing the results of total sales with total costs. profits are determined by calculating and comparing total sales results with total costs. Profit is the difference between the total sales results obtained and the total costs incurred. Profits will reach maximum if the difference between the two is maximum. In this first way the maximum profit will be achieved if the difference in value between the total sales proceeds and the total cost is the maximum. According to Sutrisno (2009: 16) "profitability is the company's ability to generate profits with all the capital that works in it. Brigham and Houston (2009: 109) "Profitability is the end result of a number of policies and decisions made by the company". Based on the opinions of the experts above it can be concluded that company is able to generate profits by using their existing resources. This study aims to examine whether business of Electrical Appliance StoreSidoarjo electrical appliance reached maximum profit?

1) Has the business of electrical appliance store in Sidoarjo reached maximum profit?

2) How many product for sales quantities provide maximum profit at the Electrical Appliance Storeelectrical appliance store in Sidoarjo?

3) What is the strategy to achieve maximum profit from the Electrical Appliance Storeelectrical appliance store in Sidoarjo?

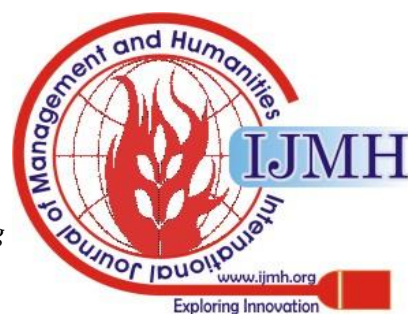




\section{Maximum Profit on the Electrical Appliance Store in Sidoarjo}

\section{RESEARCH OBJECTIVES}

The specific objectives to be achieved in this study are to find out and analyze:

1) The large quantity of products (Qmaks) for sale that provide maximum profits in the electrical equipment shop Electrical Appliance Store Sidoarjo.

2) Opportunities and threats of business equipment stores Electrical Appliance Store Sidoarjo.

3) Strategies for achieving the maximum profit of the Electrical Appliance Store Sidoarjo electrical appliance shop.

\section{LITERATURE REVIEW}

According to B Djatmiko, A Yulistyorini, R M Sugandi and E Setyawan (2019) Profit is the primary goal of entrepreneurs in general and construction contractors in particular. This is because profits are used for company survival, development, trust and working capital to get the next project Profit Maximization assumes 'Perfect Competition' like market conditions. The operating logic and backbone of this approach is 'efficiency'. Put in simple terms, 'efficiency' refers to minimizing inputs and maximizing outputs (Zubair Ahmad Khan, 2017). Profit optimization becomes the main goal of each production process. For the achievement itself, required precise calculations and analysis in order to support the achievement of maximum profit. The maximum profit can be achieved with proper production planning (Mabafasa $\mathrm{Al}$ Khuluqi , Wayan Firdaus Mahmudy , Asyrofa Rahmi, 2016).

Total Cost (TC) is generated by the sum of Fixed Cost (FC) and Variable Cost (VC) (Suprapto Soemardan, Widodo Wahyu Purwanto, and Arsegianto, 2013). Sales revenues are an item of the income statement, which is the total income that the entity receives as cash flows or an increase in other assets from the main activities resulting from the exercise of its principal activity,

whether from the sale of its commodity products or services. This item can be divided into other detailed items for each product or service. The net revenue is the main figure in the financial statements and is the basis for many calculations and analyzes, and an important indicator of the performance and marketing ability to sell the product (Mohammad Ali AL Hayek 2108).

\section{RESEARCH METHOD}

The research method used in this study is a quantitative descriptive research method that is research that processes quantitative data and then the results of these calculations are analyzed with existing theories. The data used are primary data obtained using interview research instruments and documentation. In this research, the object of research is the businessman of electrical appliance shops Electrical Appliance Store in Sidoarjo, by using a case study technique. Purposive case selection is based on a particular consideration made by the researcher himself, based on the characteristics or properties of the object that are already known in advance. Purposeful selection of cases includes researchers identifying all characteristics of objects by conducting a preliminary study by studying various related

matters. Then the researcher determines based on his consideration that some of the members of the object become cases to be investigated, so that the purposive case selection technique is based on the researchers' personal considerations.

Data analysis uses the analysis of the maximum profit of a perfectly competitive market company, by:

1) Maximum profit; where the difference in value between total sales $($ Total Revenue $=\mathrm{TR})$ and total costs $($ Total Cost $=\mathrm{TC})$ is maximum $(\pi)$, where: $\pi=\mathrm{TR}-\mathrm{TC}$

2) Maximum profit; where marginal cost (MC) equals marginal sales (Marginal Revenue $=\mathrm{MR}$ ) or $\mathrm{MR}=\mathrm{MC}$, or the first derivative value of $\pi$ is zero $\left(\pi^{\prime}=0\right)$

3) If the company is in the condition of $\mathrm{MR}>\mathrm{MC}$, then what is done is to increase production to increase profits. Conversely, if MC> MR, additional production will actually reduce profits, so the company must reduce production. The hypothesis raised in this research is Electrical Appliance Store Sidoarjo has not reached the maximum profit.

\section{ANALYSIS AND DISCUSION}

The data were collection by interview and documentation method in Electrical Appliance Store in Sidoarjo, Indonesia. The data obtained is:

1. Sales data of Electrical Appliance Store, Sidoarjo period October 2019 - March 2020

2. Product purchase data of Electrical Appliance Store, Sidoarjo period October 2019 - March 2020

3. From the data obtained a mathematical model is arranged using table that contains the Total Cost, Total Revenue, Marginal Cost, and Marginal Revenue.

4. The analytical tool used is the Maximum Profit Analysis with the Total Approach which compares total revenue with total cost (TR - TC), and the Marginal Appoarch method, which is a condition where marginal revenue is equal to marginal cost $(\mathrm{MR}=\mathrm{MC})$.

5. The formula looks: for $\mathrm{MC}=\Delta \mathrm{TC} / \Delta \mathrm{Q}$, and $\mathrm{MR}=$ $\Delta \mathrm{TR} / \Delta \mathrm{Q}$ for profit $=\mathrm{MR}-\mathrm{MC}$

Table-I: Maximization of profit on lamps sales (In Rupiah)

\begin{tabular}{|c|c|c|c|c|c|c|c|}
\hline $\mathrm{Q}$ & $P$ & $\begin{array}{l}\mathrm{T} \\
\mathrm{R}\end{array}$ & MR & TC & $\mathrm{MC}$ & $\begin{array}{l}\text { Prof } \\
\text { it }\end{array}$ & $\begin{array}{l}\text { Chage in } \\
\text { profit } \\
\text { ( MR- } \\
\text { MC) }\end{array}$ \\
\hline $2^{2}$ & 5 & $4^{26}$ & \} & $15^{\mathrm{J}}$ & \} & 19,5 & $-4,5$ \\
\hline $3^{2}$ & $\begin{array}{l}1 \\
5\end{array}$ & $9^{27}$ & \} & 69 ? & \} & $\begin{array}{c}5,25 \\
+\end{array}$ & 63,75 \\
\hline $5^{2}$ & 5 & $\begin{array}{l}41 \\
7\end{array}$ & \} & $2,5^{-0}$ & \} & 10,5 & -8 \\
\hline $2^{3}$ & $\begin{array}{l}1 \\
5\end{array}$ & $\begin{array}{l}43 \\
5 \\
\end{array}$ & \} & $\begin{array}{cc}1 & 1 \\
2,1 & \end{array}$ & \} & $\begin{array}{c}1015 \\
13,5\end{array}$ & \} \\
\hline $\begin{array}{l}4 \\
9 \\
\end{array}$ & 5 & $\begin{array}{l}47 \\
1\end{array}$ & \} & | $57 \overline{3}$ & \} & $1-$ & $\begin{array}{r}111 \\
-69\end{array}$ \\
\hline $\begin{array}{l}5 \\
7\end{array}$ & $\begin{array}{l}1 \\
5\end{array}$ & $\begin{array}{l}52 \\
8\end{array}$ & & $7,1 \longdiv { i 8 5 }$ & & -157 & \\
\hline
\end{tabular}

* https://www.ajarekonomi.com/ 
* The formula looks: for $\mathrm{MC}=\Delta \mathrm{TC} / \Delta \mathrm{Q}$, and $\mathrm{MR}=\Delta \mathrm{TR} /$ $\Delta \mathrm{Q}$ for profit $=\mathrm{MR}-\mathrm{MC}$

Information:

- In the table it appears that the more the amount of output sold, at first the profit has increased, but at a certain point the profit has

decreased.

- $\quad$ Look at the change in profit (MR-MC) column, there you can see how much change in profit has been made, as output sales have

increased.

- When MR> MC, to maximize profit, producers must increase the quantity of output.

When $\mathrm{MR}<\mathrm{MC}$, then to maximize profits, producers must reduce the quantity of output

- At the point where MR = MC, at that moment the maximum profit level is reached.

The results of this study indicate that the Electrical Appliance Store, power tools store has not yet reached its maximum profit. Because the maximum profit requirement is when MR = MC but in this case of study MR> MC. That means the electrical equipment store Electrical Appliance Store has not reached the point of maximum profit.

\section{CONCLUSION AND SUGGESTION}

\section{A. Conclusion}

Electrical appliance business is actually very profitable and easier to run a business. But even though it's easy, you certainly have to have the interest and intention from the heart to run this business seriously so that the money generated is always a blessing and the business that you run today is able to grow very well. Before starting a business, it is better to prepare important things that will be closely related to the business path, but if the management is not good then the business is not running. As in this case:

1. Poor financial management, this happens an imbalance between income and expenditure.

2. It is proven that seen from Table 1, that is $\mathrm{MR}>\mathrm{MC}$ it means that has not reached the maximum profit point. Because financial management cannot regulate between must be issued, and in writing financial statements are recorded in detail how much the incoming budget and the budget that come out and then for what the outgoing budget is. That's what causes business owners to not achieve maximum profit.

\section{B. Suggestion}

To increase the sales volume, the electrical appliance store should:

1. Financial management must be arranged between income and expenditure, then the financial statements are recorded in detail how much the incoming and outgoing budget and then for what the outgoing budget.

2. Try to sell in online market thus the income of this business increases otherwise the owner should reduce the cost of expenses to reach the maximum profit point.

\section{REFERENCES}

1. K. A. Effendi, "The Optimization of Capital Structure in Maximizing Profit and Corporate Value,” Binus Business Review, Vol 8(1), 2017, pp. $41-47$

2. D. Wijayanto,, F. X. Sugiyanto, and D. Poerwono, "Optimal harvest time model in aquaculture to maximize profit," International Journal of Marine and Aquatic Resource Conservation and Co-existence Research Article, Vol 2 (1), 2017, pp. 7-11

3. Z. A. Khan, "Profit Maximisation as an objective of a firm - A Robust Perspective," International Journal of Research in Finance and Marketing (IJRFM), Vol 7, 2017, pp. 217-219

4. S. S. Oberoi, "Profit Maximizing Probabilistic Inventory Model under Trade Credit," International Journal of Economics and Financial Issues, Vol 7(4), 2017, pp. 408-410

5. E. H. Kyssima1, D. N.G.A.K. Tesha, D. S. Lello, and F. S. Mtitu, "Profit Maximization Strategies Employed by the Small and Medium Size Building Contractors in Dar-Es-Salaam, Tanzania," International Journal of Engineering and Management Research, Vol 10(1), 2020, pp. 92-110

6. M. Al Khuluqi,, W. F. Mahmudy, and A. Rahmi, "Profit optimization based on total production in textile home industry using evolution strategies algorithms," International Journal of Social and Local Economic Governance (IJLEG) , Vol. 2(2), 2016, pp. 109-117

7. M. A. Al Hayek, "The Relationship Between Sales Revenue and Net Profit with Net Cash Flows from Operating Activities in Jordanian Industrial Joint Stock Companies" International Journal of Academic Research in Accounting, Finance and Management Sciences Vol. 8(3), 2018, pp. 149-162

8. B. Djatmiko, A. Yulistyorini, R. M. Sugandi, and E. Setyawan, "The application of fuzzy logic for profit optimization to contractor project cash flow," The 2nd International Conference on Green Civil and Environmental Engineering, doi:10.1088/1757-899X/669/1/012060, 2019, pp. 1-10

9. M. Yesmin, Dr. Md. A. Alim, "A New Quadratic Formulation to Ensure Maximum Profit of a Textile Industry and a Modified Harmonic Average Technique to Solve Multi Objective Quadratic Programming Problem (MOQPP)," International Journal of Science and Research (IJSR), Vol 9(2), 2020, pp. 937-943

10. Priyadharsini S, Dharani R, Y. Priya, and Karthikeyan, "Profit Optimization of CDCC Bank, As LPP." IJSRD - International Journal for Scientific Research \& Development, Vol. 4(12), 2017, pp. 567-570

11. T. D. Ailobhio, A. I. Sulaiman, and I. Akeyede, "Optimizing Profit in Lace Baking Industry Lafia with Linear Programming Model," International Journal of Statistics and Applications 2018, Vol 8(1), 2018, pp. 18-22

12. S. Ahmed, "An Approach to Maximize Profit of a Constructing Project within Limited Budget by Using Simplex Method," International Journal of Scientific \& Engineering Research, Vol 6(11), 2015, pp. 786-791

13. S. Soemardan, W. W. Purwanto, and Arsegianto, "Production Optimization for Plan of Gas Field Development Using Marginal Cost Analysis," Makara Seri Teknologi, Vol 17(2), 2013, pp. 94-102

14. J. P. Brunkhorst, A. J. Fenn, "Profit Maximization In The National Football League," The Journal of Applied Business Research, Vol 26(1), 2010, pp. 45-58

15. A. A. Choudhari, "Techniques to reduce the cost of raw material and to gain the profits," International Research Journal of Engineering and Technology (IRJET) Vol 5(8), 2018, pp. 132-135

16. M. Bahumayd, M. Kamel, "Decision Support system to Maximize Profit Using Integer programming Comparing with other Techniques," International Journal of Advanced Research in Computer and Communication Engineering, Vol. 7(1), 2018, pp. 226242

17. Srinivasan A, Kalaimani R, "Profit maximization scheme with guaranteed quality of service in cloud computing," International Journal of Pure and Applied Mathematics, Vol 119(14), 2018, pp. $1307-1316$ 
Maximum Profit on the Electrical Appliance Store in Sidoarjo

\section{AUTHORS PROFILE}

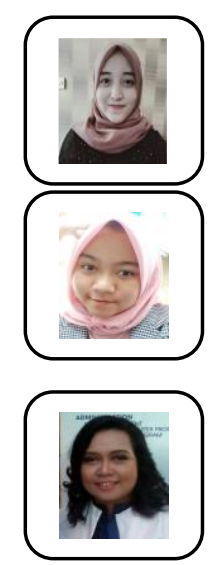

Icha Almasha Vilantika Poetri, An active undergraduate student at STIE Mahardhika, Surabaya Indonesia, major in Management.

Verina Aldera Pratama, An active undergraduate student at STIE Mahardhika, Surabaya Indonesia, major in Management.

Evi Thelia Sari,A senior lecturer at management department of STIE Mahardhika, whose main research field is in management.

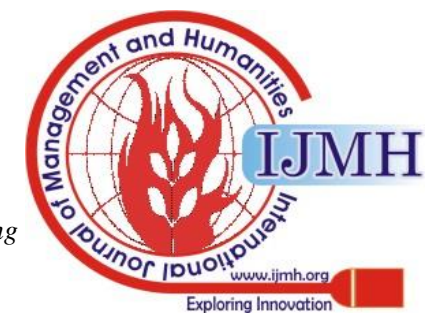

